\title{
Germination and initial development of Brachiaria brizantha and Brachiaria decumbens on exposure to cadmium, lead and copper ${ }^{1}$
}

\author{
Karine Sousa Carsten Borges², Raquel Custódio D’Avila³, Mari Lúcia Campos ${ }^{4 *}$, \\ Cileide Maria Medeiros Coelho ${ }^{5}$, David José Miquelluti ${ }^{6}$, Natiele da Silva Galvan ${ }^{7}$
}

\begin{abstract}
The objective was to evaluate the germination and initial development of three cultivars of Brachiaria brizantha and Brachiaria decumbens in the presence of trace elements of $\mathrm{Cd}, \mathrm{Pb}$ and $\mathrm{Cu}$ and quantify the $\mathrm{Cd}$ and $\mathrm{Cu}$ contents in plant tissue of these species. First, seed germination occurred in towel paper containing cadmium, lead, copper and the control. We calculated the percentage of germination, germination speed index, vigor index and seedling length. Later, the seeds were germinated in soil pots contaminated with $\mathrm{Cd}$ and $\mathrm{Cu}$, where the Soil-Plant Analysis Development index (SPAD index) was evaluated, as well as dry matter of shoot and root, and the $\mathrm{Cd}$ and $\mathrm{Cu}$ metal content in plant tissue was quantified. B. decumbens showed sensitivity to the elements studied, with decreases in all parameters. $\mathrm{Cu}$ was the element that caused more toxic effects on germination and early seedling development of the species studied. In contaminated soil, the species studied showed no differences in dry matter production of shoots, but the exposure to $\mathrm{Cd}$ and $\mathrm{Cu}$ caused reductions in SPAD index in all species. The highest $\mathrm{Cd}$ and $\mathrm{Cu}$ contents were found in the roots.
\end{abstract}

Index terms: inhibition, phytotoxicity, heavy metals.

\section{Germinação e desenvolvimento inicial da Brachiaria brizantha e Brachiaria decumbens em exposição de cádmio, chumbo e cobre}

RESUMO - O objetivo no trabalho foi avaliar a germinação e o desenvolvimento inicial de três cultivares de Brachiaria brizantha e a Brachiaria decumbens em presença dos elementos-traço $\mathrm{Cd}, \mathrm{Pb}$ e $\mathrm{Cu}$ e quantificar os teores de $\mathrm{Cd}$ e $\mathrm{Cu}$ no tecido vegetal dessas espécies. A germinação das sementes ocorreu em papel germitest ${ }^{\circledR}$, contendo cádmio, chumbo, cobre além da testemunha. Foram calculadas a porcentagem de germinação, índice de velocidade de germinação, índice de vigor e comprimento da plântula. Posteriormente, as sementes foram germinadas em vasos de solo contaminado com $\mathrm{Cd}$ e $\mathrm{Cu}$, onde se avaliou o índice Soil Plant Analysis Development (SPAD), matéria seca da parte aérea e da raiz e quantificado o teor de metais $\mathrm{Cd}$ e $\mathrm{Cu}$ no tecido vegetal. A $B$. decumbens apresentou sensibilidade aos elementos estudados, apresentando decréscimos de todos os parâmetros avaliados. $\mathrm{O} \mathrm{Cu}$ foi o elemento que mais causou efeitos tóxicos à germinação e desenvolvimento inicial das plântulas das espécies estudadas. Em solo contaminado, as espécies estudadas não apresentaram diferenças na produção de massa seca de parte aérea, porém a exposição de $\mathrm{Cd}$ e $\mathrm{Cu}$ ocasionou reduções do índice SPAD em todas as espécies. Os maiores teores de $\mathrm{Cd}$ e $\mathrm{Cu}$ foram encontrados nas raízes.

Termos para indexação: inibição, fitotoxidade, metais pesados.

\section{Introduction}

Human activity has increasingly raised trace element levels in the environment. Plants are the main entry for these elements into the food chain. Most trace elements are known as growth inhibitors and exert negative effects on plants, which

${ }^{1}$ Submitted on 6/13/2016. Accepted for publication on 10/3/2016. ${ }^{2}$ Centro Universitário Leonardo da Vinci, Grupo UNIASSELVI, 89130-000 Indaial, SC, Brasil.

${ }^{3}$ Fundação Municipal do Meio Ambiente, 88160-126 - Biguaçu, SC, Brasil. ${ }^{4}$ Departamento de Solos e Recursos Naturais, Universidade Estadual de Santa Catarina, 88520-000 - Lages, SC, Brasil. may lead to broader phytotoxicity responses and decrease the yield and quality in agricultural crops (Gratão et al., 2005; Yang et al., 2010).

Some trace elements, such as $\mathrm{Cd}$ (cadmium) and $\mathrm{Pb}$ (lead), are considered toxic even in minute concentrations, causing deleterious effects on plants. Such deleterious

${ }^{5}$ Departamento de Agronomia, Universidade Estadual de Santa Catarina, 88520-000 - Lages, SC, Brasil.

${ }^{6}$ Departamento de Solos e Recursos Naturais, Universidade Estadual de Santa Catarina, 88520-000 - Lages, SC, Brasil.

${ }^{7}$ Universidade Estadual de Santa Catarina, 88520-000 - Lages, SC, Brasil.

*Corresponding author <mari.lucia03@gmail.com> 
effects can be observed on seedling growth, changes in the structure of chloroplasts, inhibition of photosynthesis, chlorosis, induced lipidic peroxidation, suppression of germination, reduction of the root system, disturbances in plant metabolic activities and reduction of plant biomass (Guimarães et al., 2008; Gill et al., 2013).

In addition, plants may exhibit indirect effects caused by these trace elements such as inhibition of water absorption and nutrient deficiency. Mineral nutrition disorders arise from deleterious effects caused by trace elements on the metabolism of essential elements, including calcium, magnesium, potassium, iron, zinc, manganese and coppe (Kabata-Pendias, 2011).

$\mathrm{Cu}$ (copper), on the other hand, plays a significant role in physiological processes such as photosynthesis and respiration, among others (Yruela, 2009; Karimi et al., 2012). However, in environmental conditions where copper is found in excess in the soil, plants may exhibit symptoms of toxicity which culminates in physiological disturbances inhibiting plant growth (Karimi, et al., 2012; Kabata-Pendias, 2011). Toxicity caused by $\mathrm{Cu}$ causes damage and disturbance in the integrity of the thylakoid membranes and photosynthesis impairment, which result in chlorosis or necrosis and inhibition of root and shoot growth (Yruela, 2009; Fidalgo et al., 2013).

In areas contaminated by trace elements, grasses are more promising in their establishment because they are relatively easy to develop, promote rapid growth in soil cover, improve soil physical and chemical structures, help in the cycling of nutrients and increase the soil organic matter content (Amaral et al., 2012).

Among grasses, genus Brachiaria spp. stands out due to high dry matter, easy cultivation and adaptation to different soils, allowing cultivation throughout the year, and low maintenance cost of the cultivated area (Lucena et al., 2010). However, few studies are carried out with this genus on trace element contamination (Gomes et al., 2011).

The present work aims to evaluate the germination and initial development of three cultivars of the species Brachiaria brizantha (cv. Piatã, Marandu and MG 5) and the species Brachiaria decumbens in the presence of trace elements of $\mathrm{Cd}, \mathrm{Pb}$ and $\mathrm{Cu}$, and quantify the content of $\mathrm{Cd}$ and $\mathrm{Cu}$ in its plant tissue.

\section{Materials and Methods}

The experiment was conducted in two distinct stages. In the first step, the experiment was conducted in a Seed Testing Laboratory. The second part of the experiment was carried out in a greenhouse and analyses were performed in a Laboratory of Environmental Survey.

Four different Brachiaria varieties were used, being three cultivars of Brachiaria brizantha (cv. Piatã, Marandu, MG 5) and one of Brachiaria decumbens. The seeds used came from a commercial agriculture and livestock farm in the Brazilian municipality Lauro Müller, SC. Seeds purity was determined following the protocol suggested by Rules for Seed Testing (Brasil, 2009) (Table 1). Before all the tests, seeds were submitted to a sanitary treatment in a $3 \%$ solution of sodium hypochlorite for five minutes and afterwards they were washed in distilled water.

Table 1. Characterization of the physical purity of seeds of $B$. brizantha (cv. Piatã, Marandu, MG 5) and $B$. decumbens.

\begin{tabular}{lc}
\hline \multicolumn{1}{c}{ Species } & Percentage of purity \% \\
\hline B. brizantha (cv. Piatã) & 71.5 \\
B. brizantha (cv. Marandu) & 55.6 \\
B. brizantha (cv. MG 5) & 73.5 \\
B. decumbens & 66.6 \\
\hline
\end{tabular}

$1^{\text {st }}$ step-Germination test in the presence of $\mathrm{Cd}, \mathrm{Cu}$ and $\mathrm{Pb}$.

Seeds were placed on towel paper rolls for germination. In order to moisture the paper, 2.5 times the paper dry weight was used with solutions containing $\mathrm{Cd}\left(\mathrm{NO}_{3}\right)_{2}, \mathrm{~Pb}\left(\mathrm{NO}_{3}\right)_{2}$ or $\mathrm{Cu}\left(\mathrm{NO}_{3}\right)_{2}$. The concentrations used followed the agricultural research values proposed by CONAMA (National Council for the Environment) Resolution no. 420 (2009) ( 3, 180 and $200 \mathrm{mg} . \mathrm{L}^{-1}$ respectively), besides the control $\left(0 \mathrm{mg} . \mathrm{L}^{-1}\right)$. Then the rolls were kept in a Mangelsdorf-type germinator at a temperature of $25{ }^{\circ} \mathrm{C}$ with a natural photoperiod. For the experimental unit, 50 seeds were considered, with four replicates for each treatment. The seeds were evaluated by the following parameters:

Germination Percentage (GP) - It was calculated by the number of normal seedlings (shoot and root) identified on the last day of the experiment, following the recommendations by the Rules for Seed Testing (Brasil, 2009).

Germination speed index (GSI) - Evaluations were performed every 24 hours until germination stabilization, which occurred on the tenth day. Seedlings were considered germinated when they reached root length greater than 5 $\mathrm{mm}$ and there was plumule rupture. To obtain the index, the formula proposed by Maguire (1962) was applied.

Length of shoot and main root - At the end of the germination test, the length of shoot and root of each seedling was measured in centimeters.

Vigor Index (VI) - Measurement of root length multiplied by the germination percentage (Dezfuli et al., 2008).

The germination percentage data were transformed to $\operatorname{arcsen} \sqrt{x} / 100$ and trace element content data were analyzed 
after logarithmic transformation, $\mathrm{Y}=\log (\mathrm{X}+1)$. All data were submitted to analysis of variance $(\mathrm{p} \leq 0.05)$ considering a factorial arrangement of the treatments (varieties and trace elements). When statistical significance was found, the Tukey's test $(\mathrm{p} \leq 0.05)$ was used to verify the magnitude of the difference among treatments. $2^{\text {nd }}$ step - Development in a greenhouse.

Plastic pots contained $0.5 \mathrm{~kg}$ of Haplic Cambisol (profile from 0 to $10 \mathrm{~cm}$ ), collected in a natural environment in the Brazilian municipality of Lages, SC. The chemical characteristics of this soil are presented in Table 2.

Table 2. Chemical characteristics and clay in the soil sample (Haplic Cambisol) used in the experiment.

\begin{tabular}{|c|c|c|c|c|c|c|c|c|}
\hline $\mathrm{pH} \mathrm{H} \mathrm{H}_{2} \mathrm{O}$ & $\mathrm{CTC}_{\mathrm{pH} 7.0}$ & $\mathrm{Al}^{+3}$ & $\mathrm{Ca}$ & $\mathrm{Mg}$ & $\mathrm{K}$ & $\mathrm{P}$ & Clay & $\mathrm{CO}^{1}$ \\
\hline & \multicolumn{4}{|c|}{ Cmolc. $\mathrm{dm}^{-3}$} & \multicolumn{2}{|c|}{ mg. $\mathrm{dm}^{-3}$} & \multicolumn{2}{|c|}{$\%$} \\
\hline 5.0 & 35.2 & 56.1 & 3.3 & 1.0 & 52 & 0.6 & 34 & 1.4 \\
\hline
\end{tabular}

Note: ${ }^{1}$ Organic carbon.

For soil contamination, the concentrations of the elements also followed the values of agricultural research proposed by CONAMA (2009), 3 mg. $\mathrm{kg}^{-1}$ for $\mathrm{Cd}$ and $200 \mathrm{mg} \cdot \mathrm{kg}^{-1}$ for $\mathrm{Cu}$. Soil contamination occurred after soil drying and sieving in a 2-mm sieve, where each trace element represented a treatment. The soil, after being contaminated, was incubated for 30 days at humidity above field capacity to stabilize the chemical conditions.

A completely randomized design with four replications was used, with each pot receiving 10 seeds. For plants full development, soil moisture was maintained in field capacity and luminosity in natural conditions of intensity and photoperiod. The temperature remained between 15 and $25^{\circ} \mathrm{C}$ and air moisture controlled between 70 and $95 \%$.

Ten days after the plants emergence, thinning was carried out, keeping five plants in each pot, making up the experimental unit. On the $30^{\text {th }}$ day, the leaves green intensity values were measured [Soil-Plant Analysis Development index (SPAD)], obtained by means of the SPAD 502 (Konica Minolta ${ }^{\circledR}$, Tokyo, Japan) chlorophyll content portable meter in the period between $8-10 \mathrm{~h}$ am. The green intensity value considered was the average of readings carried out on five leaves having no physical damages or symptoms of pest and disease attack, randomly sampled in the five plants of each experimental unit.

After the plants development, these were collected and separated in shoot and root. The vegetative samples were washed with distilled water and dried in a forced-air circulation oven at a temperature of approximately $65^{\circ} \mathrm{C}$ until reaching constant weight. After drying, the material was weighed to evaluate the shoot dry matter (SDM) and root dry matter (RDM) yields and processed in a plant tissue grinder. Quantification of the $\mathrm{Cd}$ and $\mathrm{Cu}$ elements in the plant was carried out in the shoot and root. Samples were submitted to acid digestion in Teflon $\mathbb{}$ [polytetrafluoroethylene (PTFE)] tubes, according to the USEPA (The United States Environmental Protection Agency) 3051 method in a Multiwave 3000 (USEPA, 1994) microwave oven. In each battery a NIST 1573 A Tomato Leaves reference sample was inserted, where $0.77 \mathrm{mg} \cdot \mathrm{kg}^{-1}$ of $\mathrm{Cd}$ were obtained while what was expected was $1.52 \pm 0.04 \mathrm{mg} \cdot \mathrm{kg}^{-1}$ and $4.01 \mathrm{mg} . \mathrm{kg}^{-1}$ of $\mathrm{Cu}$ while what was expected was $4.70 \mathrm{mg} \cdot \mathrm{kg}^{-1} \pm .0 .14 \mathrm{mg} \cdot \mathrm{kg}^{-1}$. The contents of the trace elements of $\mathrm{Cd}$ and $\mathrm{Cu}$ were quantified in a high resolution atomic absorption spectrometer and electrothermal atomization (CONTRAA 700 - Analytik Jena). Reading conditions were those indicated by the manufacturer. For the available soil contents, the Tedesco (1995) methodology was used. The contents were quantified in atomic absorption spectrophotometry (AA Perkin Elemer - A Analyst 100).

Data were submitted to the Shapiro-Wilk normality tests and the homogeneity of variance Levene's test, applying the required scale transformations when appropriate. Then the data were submitted to analysis of variance according to the completely randomized design in a factorial arrangement. The Tukey's averages comparison test was used at $5 \%$ probability to discriminate the effect of factor levels when this was the case.

\section{Results and Discussion}

\section{Germination test in the presence of $C d, C u$ and $P b$.}

For species $B$. decumbens there reductions in GP in exposure to all trace elements studied (Figure $1 \mathrm{~A}$ ). The cv. Piatã, Marandu and MG 5 of B. brizantha have not presented difference in the germination percentage (GP) in exposure to $\mathrm{Cd}$. In exposure to $\mathrm{Pb}$, cultivars Piatã and Marandu have not presented GP differences either. However, cv. MG 5 has had $34 \%$ reduction in GP and B. decumbens $12 \%$ when comparing with the control.

Exposure to $\mathrm{Cu}$ has reduced GP in all species studied. However, it was for $B$. decumbens that $\mathrm{Cu}$ promoted the highest germination inhibition, because GP in exposure to $\mathrm{Cu}$ was only $1 \%$, i.e., a reduction of $99 \%$ compared to the control. 
The absorption of trace elements in brachiaria promotes oxidative stress, compromising the epidermis walls, which become thinner in relation to exodermis, resulting in the roots cellular degradation. In addition, the presence of trace elements accelerates maturation of the cell wall in mesoderm and endoderm (Gomes et al., 2011).

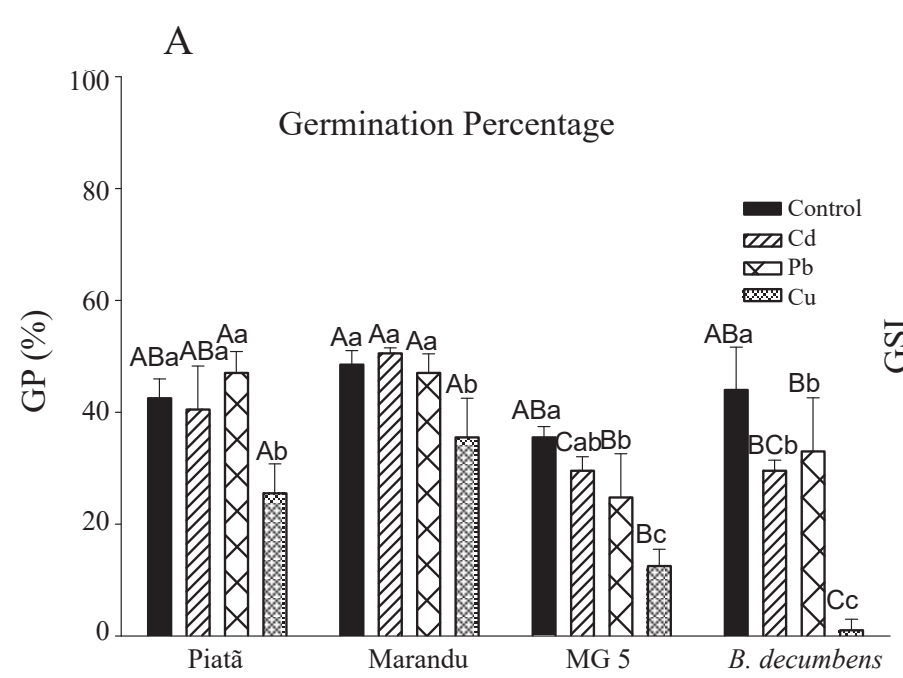

$\mathrm{B}$

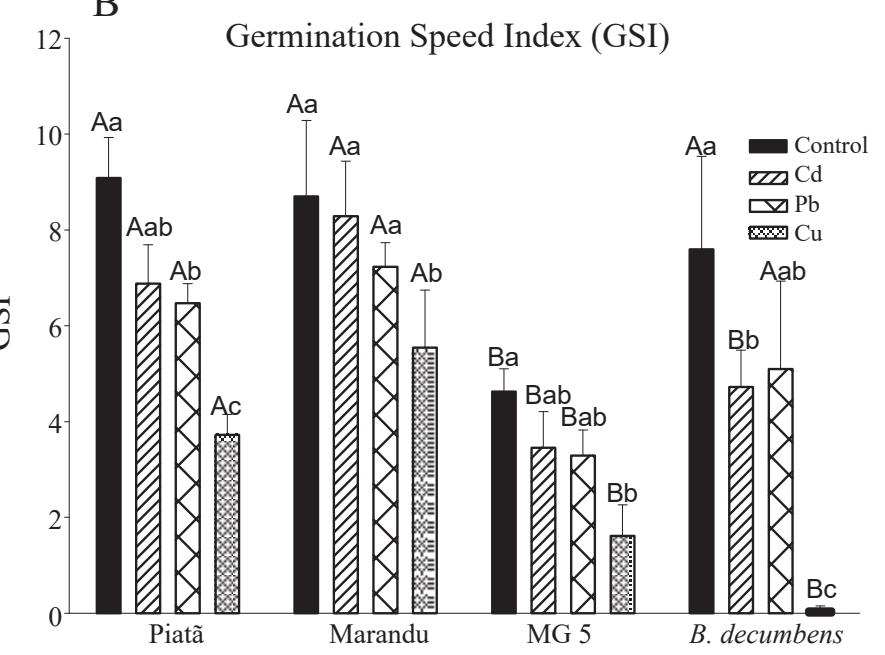

Figure 1. Germination percentage (GP) (A) and Germination speed index (GSI) (B) of species Brachiaria brizantha (cv. Piatã, Marandu and MG 5) and Brachiaria decumbens in the presence of $\mathrm{Cd}, \mathrm{Pb}$ and $\mathrm{Cu}$.

Note: Uppercase letters statistically compare species within the same treatment and lowercase letters compare treatments in the same variety.

The presence of trace elements may block the transport of water to the seeds due to the increase in the osmotic potential of the solution, resulting in a secondary effect caused by the low water absorption and not the element toxic effects on the embryo (Kranner and Colville, 2011). Nonetheless, Kalai et al., (2014) state that germination inhibition may occur due to a failure in mobilization of the endosperm caused by the decline of $\alpha$-amylase, acid phosphatase activity and alkaline phosphatase, as well as a small modification of $\beta$-amylase activity resulting in a failure in the mobilization of $\mathrm{Cd}$ and $\mathrm{Cu}$ in the endosperm.

In exposure to $\mathrm{Cd}$, cv. Piatã, Marandu and MG 5 of $B$. brizantha have not presented reductions in the germination speed index (GSI). However, in exposure to $\mathrm{Pb}$, for cv. Piatã has caused reduction of GSI from 9 (control ) to $6.5(\mathrm{~Pb})$. This reduction can be explained by germination delayed beginning on exposure to this element, which occurred two days after germination start in the control (Figure $1 \mathrm{~B}$ ). As it occurred in GP, B. decumbens presented GSI reductions in exposure to $\mathrm{Cd}$ and $\mathrm{Cu}$. In the exposure to $\mathrm{Cu}$, all species studied had a germination delay of five days compared to that of the germination beginning without the presence of trace elements. Germination delay can occur by the protective role which integument can exert on seeds, being able to block and retain trace elements on its surface. However, when the trace element is absorbed, it is deposited in the endosperm, the organ responsible for providing nutrients to the germination process, thus being able to be translocated to the embryo (Sun and Luo, 2014). On the other hand, the GSI delay when exposed to $\mathrm{Cu}$ may be the result of a reduction in nitrogen availability in the embryonic axis. This is due to the inhibition of protein synthesis resulting in decreased availability of amino acids present in the endosperm (Karmous et al., 2012).

There was no significant difference in shoot length for cultivars B. brizantha (cv. Piatã, Marandu and MG 5) in the presence of $\mathrm{Cd}, \mathrm{Pb}$ and $\mathrm{Cu}$ and for $B$. decumbens in the presence of trace elements $\mathrm{Cd}$ and $\mathrm{Pb}$ (Figure $2 \mathrm{~A}$ ). However, in the presence of $\mathrm{Cu}, B$. decumbens presented inhibition in shoot growth, which reduced from 5.5 to $1.0 \mathrm{~cm}$. The low translocation of trace elements from the root to the shoot causes the shoot to be little influenced by the seedlings exposure to the trace elements (Fidalgo et al., 2013).

In the presence of $\mathrm{Cd}$ there was a reduction of root length of 2.5 and $1.0 \mathrm{~cm}$ for cv. Piatã of B. brizantha and in $B$. decumbens respectively (Figure $2 \mathrm{~B}$ ). However, for cv. Marandu and MG 5 of $B$. brizantha there was no reduction in root length in the presence of $\mathrm{Cd}$.

In exposure to $\mathrm{Pb}$, cultivars Piatã, Marandu of $B$. brizantha and $B$. decumbens presented reductions in root length. As for exposure to $\mathrm{Cu}$, the reductions in root length could be observed in cultivars Piatã, MG 5 of $B$. brizantha and B. decumbens. In cultivars Piatã and Marandu it was observed 


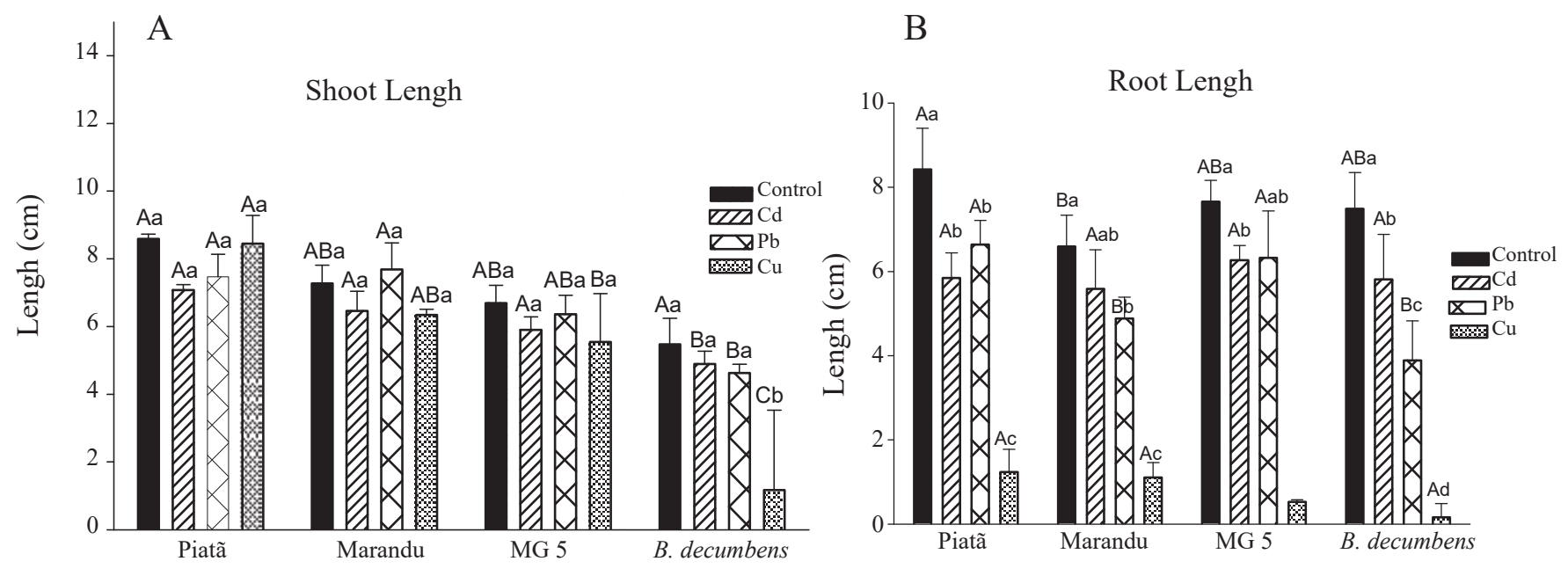

Figure 2. Shoot length (A) and root length (B) of seedlings of Brachiaria brizantha (cv. Piatã, Marandu and MG 5) and Brachiaria decumbens in the presence of $\mathrm{Cd}, \mathrm{Pb}$ and $\mathrm{Cu}$.

Note: Uppercase letters statistically compare varieties within the same treatment and lowercase letters compare treatments in the same variety.

that even when not presenting differences in GP, exposure to $\mathrm{Pb}$ caused reductions in root length. The greatest reduction of root length was observed in exposure to $\mathrm{Cu}$, with growth not exceeding $1.5 \mathrm{~cm}$ in the species studied.

Blockade of enzyme activation and reduction or direct blockage of cell division and interference in mitosis formation may explain the reduction in root growth. Repression of protein synthesis, a DNA replication, can also block cell division (Moosavi et al., 2012).

When plants are exposed to excess $\mathrm{Cu}$, this element can affect the metabolism of $\mathrm{N}$ by the reduction of nitrate reductase enzyme responsible for the root length, decrease of the amount of leaves, decrease of the plant biomass caused by the increase of $\mathrm{Cu}$ concentration in plant tissues (Xiong et al., 2006).

The presence of trace elements of $\mathrm{Cd}, \mathrm{Pb}$ and $\mathrm{Cu}$ has caused reductions in the Vigor Index (VI) in all species studied (Figure 3 ). The decrease in VI, which is a result of the low germination percentage and/or decrease in root length, can be caused by the inhibition of mitosis and the synthesis reduction of the cell wall components and in the metabolism of polysaccharides (Heidari and Sarani, 2011). As with the data obtained here, Saderi and Zarinkamar (2012) have obtained germination reductions and low root growth of Matricaria chamomilla exposed to $\mathrm{Cd}$ and $\mathrm{Pb}$. In seeds of Populus alba contaminated by Cd, Madejón et al. (2015) have not found differences in vigor of these seeds comparing with non-contaminated seeds. It is worth noting that the contamination tested by these authors was in seeds and not in the environment.

Germination is the most sensitive phase in a plant life cycle and there is no consistent test or measurable parameter valid for all possible conditions at the time of sowing, i.e., in vitro germination does not refer to the plants field development conditions (Madejón et al., 2015). Germination tests serve as a preliminary parameter to seedlings development in exposure to trace elements (Di Salvatore et al., 2008). Thus, the experiment was conducted in a second step to evaluate these conditions.

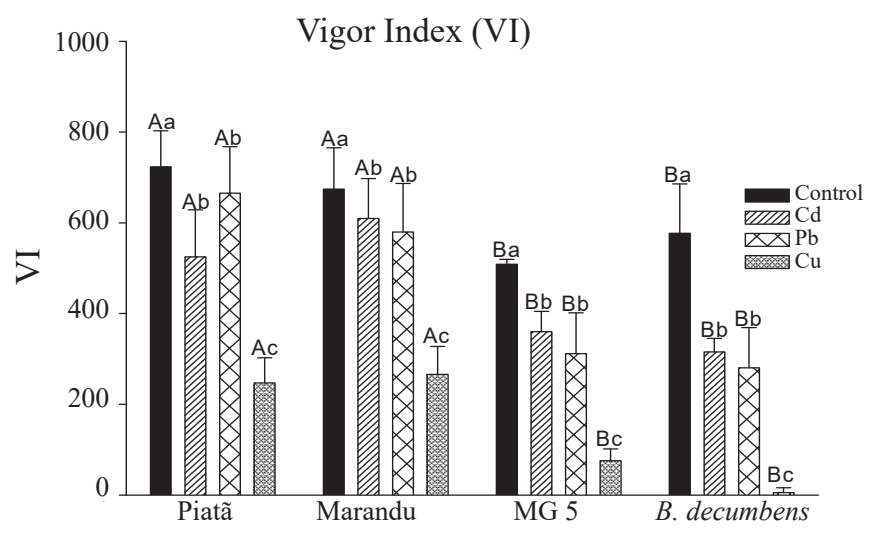

Figure 3. Vigor Index (VI) of seedlings of B. brizantha (cv. Piatã, Marandu and MG 5) and B. decumbens in the presence of $\mathrm{Cd}, \mathrm{Pb}$ and $\mathrm{Cu}$.

Note: Uppercase letters statistically compare varieties within the same treatment and lowercase letters compare treatments in the same variety.

\section{Greenhouse}

The root dry matter (RDM) results showed no interaction among the species studied and the presence or absence of $\mathrm{Cd}$ and $\mathrm{Cu}$. By means of the test of means it was observed that there were no differences among the species studied nor for the treatments studied (Table 3). 
There was an interaction between the shoot dry matter (SDM) and cultivars of $B$. brizantha and B. decumbens. Exposure to $\mathrm{Cd}$ has caused an increase of SDM from 1028.2 to $1457.8 \mathrm{mg}$ for cv. MG 5 of B. brizantha (Table 3). The presence of $\mathrm{Cu}$ has increased SDM from 483.4 to $836.2 \mathrm{mg}$ in $\mathrm{cv}$. Marandu of $B$. brizantha, an increase of $57.8 \%$ when compared to the control. However, for cv. Piatã of B. brizantha and for $B$. decumbens there was no difference among treatments.

Table 3. Dry matter (mg. $\left.\mathrm{kg}^{-1}\right)$ of the plant tissue of the species B. brizantha (cv. Piatã, Marandu and MG 5) and B. decumbens $(\mathrm{Dec})$ in the absence and presence of trace elements of $\mathrm{Cd}$ and $\mathrm{Cu}$.

\begin{tabular}{ccccccccc}
\hline \multirow{2}{*}{ Cultivars } & \multicolumn{3}{c}{ Shoot (SDM) } & \multicolumn{5}{c}{ Root (RDM) } \\
\cline { 2 - 9 } & Control & $\mathrm{Cd}$ & $\mathrm{Cu}$ & Mean & Control & $\mathrm{Cd}$ & $\mathrm{Cu}$ & $\mathrm{Mean}$ \\
\hline Piatã & $893.8 \mathrm{Ba}$ & $902.5 \mathrm{Aa}$ & $902.3 \mathrm{Ba}$ & 899.6 & 767.5 & 729.5 & 736.7 & $744.6 \mathrm{~A}$ \\
Marandu & $483.4 \mathrm{Cb}$ & $836.2 \mathrm{Aa}$ & $891.3 \mathrm{Ba}$ & 737.0 & 751.3 & 681.8 & 922.4 & $785.2 \mathrm{~A}$ \\
MG5 & $1457.9 \mathrm{Aa}$ & $1028.2 \mathrm{Ab}$ & $1596.7 \mathrm{Aa}$ & 1361.0 & 776.4 & 805.8 & 850.2 & $810.8 \mathrm{~A}$ \\
Dec & $1135.8 \mathrm{ABa}$ & $1180.8 \mathrm{Aa}$ & $1129.5 \mathrm{Ba}$ & 1148.7 & 569.5 & 697.3 & 773.8 & $680.2 \mathrm{~A}$ \\
Mean & 992.7 & 987.0 & 1130.00 & & $716.2 \mathrm{a}$ & $728.6 \mathrm{a}$ & $820.8 \mathrm{a}$ & \\
\hline
\end{tabular}

Note: The representation of the uppercase letters statistically compare species within the same treatment and lowercase letters compare treatments within the same variety.

Andrade et al. (2014) have observed that exposure of $B$. decumbens to $\mathrm{Ba}$ and $\mathrm{Pb}$ has not resulted in differences in dry matter weight either. Exposure of brachiaria to trace elements may result in the production of phytochelatins and antioxidant compounds such as ascorbate and tocopherol, which minimizes the toxic effects of trace elements (Santos et al., 2011).

An indication of tolerance to plant exposure to trace elements is the dry matter weight proportionality between the absence and presence of these contaminants (Andrade et al., 2014; Tolentino et al., 2014). This has been observed in this study for $B$. decumbens and for cultivar MG 5.

There was a reduction in the SPAD index in all species studied in exposure to $\mathrm{Cd}$ and $\mathrm{Cu}$ (Figure 4). The negative effect caused by plant exposure to $\mathrm{Cd}$ and $\mathrm{Cu}$ is reflected in the indirect measure of the chlorophyll content by the SPAD index (Marchiol et al., 2004). The cv. Piatã of B. brizantha was the one which presented the highest reductions in the SPAD index from 27 in the absence of trace elements to 19 in the presence of $\mathrm{Cd}$ and 18 in the presence of $\mathrm{Cu}$. Santos et al. (2013) have found reductions in the SPAD index in Phaseolus vulgaris L. in exposure to increasing doses of $\mathrm{Cd}$. The uptake of $\mathrm{Cd}$ in plants can cause disorganization of chloroplast structures and reduction of chlorophyll biosynthesis, interfering with photosynthesis, respiration and water relations (Gill et al., 2013). The levels of chlorophyll, of the enzymes activity of the Calvin cycle and photosystem II (or waterplastoquinone oxidoreductase) are susceptible to trace elements. In combination, both directly and indirectly, these factors contribute to the reduction of carbon assimilation (Gomes et al., 2011).

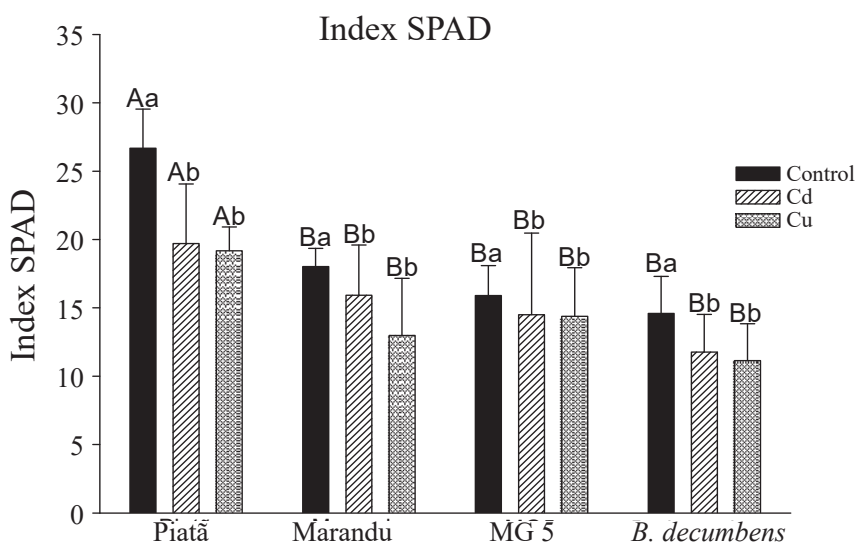

Figure 4. SPAD (Soil Plant Analysis Development) index of species Brachiaria brizantha (cv. Piatã, Marandu and MG 5) and Brachiaria decumbens in the presence of $\mathrm{Cd}$ and $\mathrm{Cu}$.

Uppercase letters statistically compare varieties within the same treatment and lowercase letters compare treatments in the same variety.

The root tissue showed higher levels of $\mathrm{Cd}$ and $\mathrm{Cu}$ compared to the shoot for all species studied, as can be seen in Table 4. There was no statistical difference between the levels of $\mathrm{Cd}$ found in the roots of all cultivars of $B$. brizantha and $B$. decumbens. Cd contents in shoot have not differed among cv. Piatã, Marandu of B. brizantha and B. decumbens. As for cv. MG 5 of $B$. brizantha it presented the lowest content of $\mathrm{Cd}$. Resistance to trace elements may be based on an exclusion mechanism in which the element accumulates in the roots and its translocation to the shoot is prevented (Rui et al., 2015).

The presence of trace elements may cause changes in size, shape and arrangement of cortical parenchyma in $B$. decumbens cells. These changes indicate an interference of 
these trace elements in the root maturation rate, possibly caused by the ability of these contaminants to disturb the plant hormonal balance. The cell walls thickening in the root may indicate a greater area supply for retention of the trace elements, reducing their translocation to the shoot (Gomes et al., 2011).

Table 4. $\mathrm{Cd}$ and $\mathrm{Cu}$ content in the plant tissue of species B. brizantha cv. Piatã, Marandu, MG 5 and B. decumbens (Dec) in the absence and presence of these elements.

\begin{tabular}{cccccc}
\hline & Cultivars & Shoot & Root & Shoot & Root \\
\cline { 2 - 6 } Absence & & \multicolumn{2}{c}{ Content of Cd mg.kg-1 } & \multicolumn{2}{c}{ Content of Cu mg.kg } \\
& Piatã & $0.40 \mathrm{Ab}$ & $1.19 \mathrm{Ab}$ & $0.94 \mathrm{Cb}$ & $8.22 \mathrm{Bb}$ \\
& Marandu & $1.30 \mathrm{Ab}$ & $1.47 \mathrm{Ab}$ & $5.88 \mathrm{Ab}$ & $12.26 \mathrm{Bb}$ \\
& MG5 & $0.56 \mathrm{Ab}$ & $0.87 \mathrm{Bb}$ & $2.30 \mathrm{Bb}$ & $12.77 \mathrm{Ba}$ \\
& Dec & $0.86 \mathrm{Ab}$ & $1.44 \mathrm{Ab}$ & $5.40 \mathrm{Ab}$ & $14.20 \mathrm{Ab}$ \\
\hline \multirow{3}{*}{ Presence } & Piatã & $1.95 \mathrm{Aa}$ & $5.22 \mathrm{Aa}$ & $8.25 \mathrm{Aa}$ & $13.15 \mathrm{Ba}$ \\
& Marandu & $2.99 \mathrm{Aa}$ & $3.22 \mathrm{Aa}$ & $9.03 \mathrm{Aa}$ & $15.77 \mathrm{Ba}$ \\
& MG5 & $1.43 \mathrm{Ba}$ & $3.35 \mathrm{Aa}$ & $5.32 \mathrm{Aa}$ & $12.96 \mathrm{Ba}$ \\
& Dec & $2.41 \mathrm{Aa}$ & $2.77 \mathrm{Aa}$ & $9.06 \mathrm{Aa}$ & $30.80 \mathrm{Aa}$ \\
\hline
\end{tabular}

Note: The representation of the uppercase letters statistically compare species within the same treatment and lowercase letters compare treatments in the same variety.

Differences of accumulation in different cultivars of the same species were also verified by Rui and contributors (2015). These authors have observed that cultivars of species Vicia sativa L. have presented sensitivity differences to Cd. In another study with wheat, concentration differences of $\mathrm{Cd}, \mathrm{Pb}, \mathrm{Zn}, \mathrm{Cu}, \mathrm{Ni}$ and $\mathrm{Cr}$ were found in different cultivars cultivated in soils contaminated with domestic sewage sludge (Jamali et al,. 2009).

Santos et al. (2006) have observed an increase of up to 2.7 times in the absorption of $\mathrm{Cd}$ in Brachiaria decumbens after the application of phytochelines, showing that this species can also increase its remediation power in contaminated soils.

Contrary to germination observed in laboratory, the presence of a high concentration of $\mathrm{Cu}$ has not caused a phytotoxic effect for the plants evaluated in a greenhouse. This is possibly the result of $\mathrm{Cu}$ ability to be complex with organic matter, binding to the functional carboxylic and phenolic groups (Kim et al., 1999). Cu content available, observed in Table 5, is four times lower than the dose applied to the soil (200 mg. $\mathrm{kg}^{-1}$ ). The same was not observed for $\mathrm{Cd}$, where the content available obtained was of $2.8 \mathrm{mg} \cdot \mathrm{kg}^{-1}$, similar to the dose applied to the soil $\left(3 \mathrm{mg} \cdot \mathrm{kg}^{-1}\right)$.

Table 5. Available cadmium and copper (mg.kg-1) content found in Haplic Cambisol in the absence and presence of contamination.

\begin{tabular}{lcr}
\hline & $\mathrm{Cd}$ & $\mathrm{Cu}$ \\
\hline Absence & 0.83 & 1.64 \\
Presence & 2.88 & 52.97 \\
\hline
\end{tabular}

In exposure to $\mathrm{Cu}, B$. decumbens was the species with the highest $\mathrm{Cu}$ content in its root tissue and no phytotoxic effect was observed in plants of $B$. decumbens when in exposure to $\mathrm{Cu}$. This result may be related to lower $\mathrm{Cu}$ availability in the soil and low $\mathrm{Cu}$ translocation for the shoot.

\section{Conclusions}

B. decumbens is more sensitive to the exposure of $\mathrm{Cd}$, $\mathrm{Pb}$ and $\mathrm{Cu}$.

B. decumbens presents germination inhibition, decrease in germination speed index and vigor index. These effects were less evident for cultivars Piatã, Marandu and MG 5 of B. brizantha.

The Vigor Index reduction measured by root length is more sensitive to the presence of $\mathrm{Cd}, \mathrm{Pb}$ and $\mathrm{Cu}$ for the species studied. Shoot length is not affected in the presence of the same elements.

In the germination test, $\mathrm{Cu}$ is the trace element that caused the most damage to the germination and initial development of $B$. brizantha (cv. Piatã, Marandu and MG 5) and $B$. decumbens seedlings.

The exposure to $\mathrm{Cu}$ causes toxicity to all species studied.

There is no difference in root dry matter production among plants cultivated in the absence and presence of $\mathrm{Cd}$ and $\mathrm{Cu}$ in the soil.

The presence of $\mathrm{Cd}$ and $\mathrm{Cu}$ in the soil results in a reduction of the SPAD (Soil Plant Analysis Development) index for $B$. brizantha (cv. Piatã, Marandu and MG 5) and B. decumbens.

The highest contents of $\mathrm{Cd}$ and $\mathrm{Cu}$ are found in roots of all species studied.

B. decumbens presents the highest contents of $\mathrm{Cu}$ in its root.

Journal of Seed Science, v.38, n.4, p.335-343, 2016 


\section{References}

AMARAL, C. S.; SILVA, E. B.; AMARAL, W. G.; NARDIS, B. O. Crescimento de Brachiaria brizantha pela adubação mineral e orgânica em rejeito estéril da mineração de quartizito. Bioscience Journal, v.28, n.1, p.130-141, 2012. http://www.seer.ufu.br/index.php/biosciencejournal

ANDRADE, A. F. M.; AMARAL SOBRINHO, N. M. B.; SANTOS, F. S.; MAGALHÃES, M. O. L.; TÓLON-BECERRA, A.; LIMA, L.S. EDTAinduced phytoextraction of lead and barium by brachiaria $(B$. decumbens cv. Basilisk) in soil contaminated by oil exploration drilling waste. Acta Scientiarum. Agronomy, v. 36, n. 4, p. 495-500, 2014. http://www.scielo.br/ scielo.php?pid=S1807-86212014000400015\&script=sci_arttext\&tlng=pt

BRASIL. Ministério da Agricultura, Pecuária e Abastecimento. Regras para análise de sementes. Ministério da Agricultura, Pecuária e Abastecimento. Secretaria de Defesa Agropecuária. Brasília: MAPA/ACS, 2009. 395p. http:// www.agricultura.gov.br/arq_editor/file/2946_regras_analise_sementes.pdf

CONAMA - Conselho Nacional do Meio Ambiente. Resolução 420, de 28 de dezembro de 2009. <http://www.mma.gov.br/port/conama/legiabre. cfm?codlegi $=620>$ Accessed on: Feb, $26^{\text {th }}, 2014$.

DEZFULI, P. M.; SHARIFZADEH, P. F.; JANMOHAMMADI, M. Influence of priming techniques on seed germination behavior of maize inbred lines (Zea mays L.) ARPN. Journal of Agricultural and Biological Science, v.3, p.22-25, 2008. http://citeseerx.ist.psu.edu/viewdoc/ download?doi=10.1.1.634.3942\&rep=rep1\&type $=$ pdf

DI SALVATORE, M.; CARAFA, A.M.; CARRATÙ, G. Assessment of heavy metals phytotoxicity using seed germination and root elongation tests: A comparison of two growth substrates. Chemosphere, v.73, p.1461-1464, 2008. http://www.sciencedirect.com/science/article/pii/S0045653508009831

FIDALGO, F.; FIDALGO, F.; AZENHA, M.; SILVA, A. F.; SOUSA, A.; SANTIAGO, A.; FERRAZ, P.; TEIXEIRA, J. Copper-induced stress in Solanum nigrum $\mathrm{L}$. and antioxidant defense system responses. Food and Energy Security, v.2, n.1, p.70-80, 2013. http://onlinelibrary.wiley.com/ doi/10.1002/fes3.20/full

GILL, S.S.; HASANUZZAMAN, M.; NAHAR, K.; MACOVEI, A.; TUTEJA, N. Importance of nitric oxide in cadmium stress tolerance in crop plants. Plant Physiology and Biochemistry, v.63, p. 254-261, 2013. http:// www.sciencedirect.com/science/article/pii/S0981942812003488

GOMES, M. P.; MARQUES, T. C. L. L. S. M.; NOGUEIRA, M. O. G.; CASTRO, E. M.; SOARES, A. M. Ecophysiological and anatomical changes due to uptake and accumulation of heavy metal in Brachiaria decumbens. Scientia Agricola, v.68, n.5, p.566-573, 2011. http://www.scielo. br/scielo.php?pid=S0103-90162011000500009\&script $=$ sci_arttext\&tlng=pt

GRATÃO, P. L.; PRASAD, M.N.V.; CARDOSO, P.F.; LEA, P.J.; AZEVEDO, R.A. Phytoremediation: green technology for the clean up of toxic metals in the environment. Brazilian Journal of Plant Physiology, v.17, n.1, p.53-64, 2005. http://www.scielo.br/scielo.php?pid=S167704202005000100005\&script=sci_arttext

GUIMARÃES, M. A.; SANTANA, T.A.; SILVA, E.V.; ZENZEN, I.L.; LOUREIRO, M. E. Toxicidade e tolerância ao cádmio às plantas. Revista Trópica-Ciências Agrárias e Biológicas, v.3, n.1, p.58-68, 2008. https:// www.researchgate.net/profile/Marcelo_Guimaraes/publication/246044549_ Cadmium toxicity and tolerance in plants (Toxicidade e tolerncia ao cdmio_em_plantas)/links/0046351d8d6eb6c6ee000000.pdf
HEIDARI, M.; SARANI, S. Effects of lead and cadmium on seed germination, seedling growth and antioxidant enzymes activities of mustard (Sinapis arvensis L.). Agricultural and Biological Science, v.6, p.44-47, 2011. https:// www.researchgate.net/profile/Mostafa_Heidari/publication/267942856_ Effects_of_lead_and_cadmium_on_seed_germination_seedling_growth and_antioxidant_enzymes_activities_of_mustard_Sinapis_arvensis_L/ links/5630fb0c08ae506cea676298.pdf

JAMALI, M. K.; KAZI, T. G.; ARAIM, M. B.; AFRIDI, H. I.; JALBANI, N.; KANDHRO, G. A.; SHAH, A. Q.; BAIG, J. A. Heavy metal accumulation in different varieties of wheat (Triticum aestivum L.) grown in soil amended with domestic sewage sludge. Journal of Hazardous Materials, v.164, n.23, p.1386-1391, 2009. http://www.sciencedirect.com/science/article/pii/ S0304389408013915

KABATA-PENDIAS, A. Trace elements in soils and plants. 4 ed. Boca Raton: CRC Press, 2011. 534p.

KALAI, T.; KHAMASSI, K.; SILVA, J. A. T.; GOUIA, H.; BEM-KAAB, L. B. Cadmium and cooper stress affect seedling grownth and enzymatic activities in germinating barley seeds. Archives of Agronomy and Soil Science, v.60, n.6, p.765-783, 2014. http://www.tandfonline.com/doi/abs/10. $1080 / 03650340.2013 .838001$

KARIMI, P.; KHAVARI-NEJAD, R. A.; NIKNAM, V.; GHAHREMANINEJAD, F.; NAJAFI, F. The effects of excess copper on antioxidative enzymes, lipid peroxidation, proline, chlorophyll, and concentration of $\mathrm{Mn}, \mathrm{Fe}$, and $\mathrm{Cu}$ in Astragalus neo-mobayenii. The Scientific World Journal, v. 2012, p.1-6, 2012. https://www.hindawi.com/journals/tswj/2012/615670/abs/

KARMOUS, I.; KHADIJA, J.; CHAOUI, A.; EL FERJANI, E. Proteolytic activities in Phaseolus vulgaris cotyledons under copper stress. Physiology and Molecular Biology of Plants, v.18, n.4, p.337-343, 2012. http://link.springer.com/article/10.1007/s12298-012-0128-4

KIM, S. D.; MA, H.; ALLEN, H. E.; CHA, D. K. Influence of dissolved organic matter on the toxicity of copper to Ceriodaphnia dubia: Effect of complexation kinetics. Environmental Toxicology and Chemistry, v.18, n.11, p.2433-2437, 1999. http://onlinelibrary.wiley.com/doi/10.1002/etc.5620181108/full

KRANNER, I.; COLVILLE, L. Metals and seeds: Biochemical and molecular implications and their significance for seed germination. Environmental and Experimental Botany, v.72, p. 93-105, 2011. http://www.sciencedirect.com/ science/article/pii/S0098847210001164

LUCENA, R. B.; PIEREZAN, F.; KOMMERS, G. D.; IRIGOYEN, L. F.; FIGHERA, R. A.; BARROS, C. S.L. Doenças de bovinos no Sul do Brasil: 6.706 casos. Pesquisa Veterinária Brasileira, v.30, n.5, p. 428-434, 2010. http://www.scielo.br/pdf/pvb/v30n5/a10v30n5

MADEJÓN, P.; CANTOS, M.; JIMÉNEZ-RAMOS, M. C.; MARAÑÓN, T.; MURILLO, J. M. Effects of soil contamination by trace elements on white poplar progeny: seed germination and seedling vigour. Environmental Monitoring and Assessment, v.187, n.11, p.663-674, 2015. http://link springer.com/article/10.1007/s10661-015-4893-8

MAGUIRE, J. D. Speed of germination aid in selection and evaluation for seedling emergence and vigor. Crop Science, v. 2, n. 1, p. 176-177, 1962.

MARCHIOL, L.; ASSOLARI, S.; SACCO, P.; ZERBI, G. Phytoextraction of heavy metals by canola (Brassica napus) and radish (Raphanus sativus) grown on multicontaminated soil. Environmental Pollution, v.132, p.21-27, 2004. http://www.sciencedirect.com/science/article/pii/S0269749104001423 
MOOSAVI, S. A.; GHARINEH, M. H.; AFSHARI, R. T.; EBRAHIMI, A. Effects of some heavy metals on seed germination characteristics of canola (Brassica napus),wheat (Triticum aestivum) and safflower (Carthamus tinctorious) to evaluate phytoremediation potential of these crops. Journal of Agricultural Science, v.4, n.9, p.11-19, 2012. http://www.ccsenet.org/journal/ index.php/jas/article/view/15599

RUI, H. CHEN, C.; ZHANG, X.; ZHANG, F.; SHEN, Z. Cd-induced oxidative stress and lignification in the roots of two Vicia sativa $\mathrm{L}$. varieties with different Cd tolerances. Journal of Hazardous Materials, v.15, p.30045-30050, 2015. http://www.sciencedirect.com/science/article/pii/S0304389415300455

SADERI, S.Z.; ZARINKAMAR, F. The effect of different $\mathrm{Pb}$ and Cd concentrations on seed germination and seedling growth of Matricaria chamomilla. Advances in Environmetal Biology, v.7, n.6, p.1940-1943, 2012. https://www.researchgate.net/ profile/Zohreh_Saderi/publication/285588494_The_effect_of_different_Pb_and Cd_concentrations_on_seed_germination_and_seedling_growth_of_Matricaria_ chamomilla/links/56607a6308ae418a7866604e.pdf

SANTOS, F. S.; HERNÁNDEZ-ALLICA, J.; BECERRIL, J. M.; AMARALSOBRINHO, N.; MAZUR N.; GARBISU, C. Chelate-induced phytoextraction of metal polluted soils with Brachiaria decumbens. Chemosphere, v.65, n.1, p.43-50, 2006. http://www.sciencedirect.com/science/journal/00456535

SANTOS, F. S.; AMARAL SOBRINHO, N. M. B.; MAZUR, N.; GARBISU, C.; BARRUTIA, O.; BECERRIL, J. M. Resposta antioxidante, formação de fitoquelatinas e composição de pigmentos fotoprotetores em Brachiaria decumbens Stapf submetida à contaminação com Cd e Zn. Química Nova, v. 34, n. 1, p. 16-20, 2011. http://www.scielo.br/pdf/qn/v34n1/v34n1a04

SANTOS,A.P.;FAGAN,E.B.;TEIXEIRA,W.F.;SOARES,L.H.;REIS, M.R.; CORRÊIA, L. T. Influência de doses de cádmio na emergência e no crescimento do feijoeiro. Revista do Centro Universitário de Patos de Minas, v.4 p.1-8, 2013. http://revistaagrociencias.unipam.edu.br/documents/57126/179380/ Influ $\% \mathrm{C} 3 \%$ AAncia + de + doses + de $+c \%$ C3 $\%$ A 1 dmio.pdf

SUN, J. L.; LUO, L. Q. A study on distribution and chemical speciation of lead in corn seed germination by synchrotron radiation X-ray fluorescence and absorption near edge structure spectrometry. Chinese Journal of Analytical Chemistry, v.10, n.42, p.1447-1452, 2014. http://www.sciencedirect.com/ science/article/pii/S187220401460774X
TEDESCO, M.J.; VOLKWEISS, S.J.; BOHNEN, H. Análises de solo, plantas e outros materiais. Porto Alegre: Departamento de solos, UFRGS 118 p. (Boletim Técnico), 1995.

TOLENTINO, T.; BERTOLI, A.; CARVALHO, R.; BASTOS, A. R.; PIRES, M. Especiação do cádmio em Brachiaria brizantha e biodisponibilidade dos macro e micronutrientes. Ciências Agrárias, v.37, n.3, p.292-298, 2014. http://www.scielo.mec.pt/scielo.php?script=sci arttext\&pid=S0871018X2014000300005

USEPA. U.S. Environmental Protection Agency. Microwave assisted acid digeston of sediments, sludges, soils and soils. Method 3051. Office of Solid Wast and Emergency Response, U.S. Government Printing Office, Washington, DC, 1994. <http://www.epa.gov.epaoswer/hazwaste/test/ pdfs/3051.pdf $>$ Acessed on Apr.4 ${ }^{\text {th }}, 2015$.

XIONG, Z.; LIU, C.; GENG, B. Phytotoxic effects of copper on nitrogen metabolism and plant growth in Brassica pekinensis Rupr. Ecotoxicology and Environmental Safety, v.64, p.273-280, 2006. http://www.sciencedirect.com/ science/article/pii/S0147651306000431

YANG, Y.; WEI, X.; LU, J.; YOU, J.; WANG, W.; SHI, R. Lead-induced phytotoxicity mechanism involved in seed germination and seedling growth of wheat (Triticum aestivum L.). Ecotoxicology and Environmental Safety, v.73, n.8, p.1982-1987, 2010. http://www.sciencedirect.com/science/article/ pii/S014765131000254X

YRUELA, I. Copper in plants: acquisition, transport and interactions Functional Plant Biology, v.36, p. 409-430, 2009. http://www.publish.csiro. $\mathrm{au} / \mathrm{fp} / \mathrm{FP} 08288$ 